\title{
The rearing system of Black Bengal Goat and their farmers in West Bengal, India
}

\author{
Debraj Nandi, Sukanta Roy, Santanu Bera, Shyam Sundar Kesh, Ashis Kumar Samanta \\ West Bengal University of Animal \& fishery Sciences, \\ Kolkata - 700037, West Bengal, India. \\ * Corresponding author email : deb.publication@gmail.com \\ Published online at www. veterinaryworld.org on 25-03-2011
}

\begin{abstract}
Bengal Goat is a precious germplasm of West Bengal. Mostly the women (91.3\%) of the farming families in West Bengal rear goat. Goat rearing is a subsidiary income source to rural poor along with agriculture. In majority of cases the flock size ranges from 1 to $4(56 \%)$. Male female ratio in adult flock is observed as 1:8 in field condition. The animals are mostly housed along with residential housing $(67.1 \%)$; houses are mostly kachha type $(82.63 \%)$ with earthen floor $(86.47 \%)$ and straw roof $(91.33 \%)$. All most all the farmers used to graze their goats for feeding. Ponds water is the major source for drinking water $(58.14 \%)$ of goats. Black Bengal Goats have natural resistant power to many diseases but are vulnerable to cold, water logging situation, diarrhoea, ecto and entro parasitic infestation and respiratory diseases. Under field condition mortality rate is $9.63 \%$.
\end{abstract}

Key words: Bengal Goat, Socio economics, Rearing System, Flock information.

\section{I ntroduction}

India has a vast reserve of goat with around $15 \%$ of world population (807million) to rank $2^{\text {nd }}$ in the World (FAO STAT, 2005). The state of West Bengal ranks first (15.07 million) in India (123 million) (Annual Report, 2007-08, Govt. of West Bengal) and possesses a valuable genetic resource of dwarf Goats, known as Black Bengal Goat (Syn. Bengal Goat).

Evidence from population structure and novel lineages in Indian goats suggested domestication started 10,000 years ago (Manjunath B. et.al). The goats of hircus species reached undivided Indian subcontinent from the Western Asia by North Western and North Eastern routes between 7500-7000 B.C. However, history of origin of the Bengal breed (Syn. Black Bengal Goat) is inadequate. It is believed that this breed is domesticated with early human colonizers to its breeding tract. The early goats must have undergone a long adaptation to local ecology and have taken the present shape of Bengal Goat.

The breed is distributed throughout West Bengal and adjoining parts of the neighboring states, like Bihar, Jharkhand, Orissa, Assam and parts of Tripura. But the expression of genes related to valuable traits gets gradually diluted and considerably lost due to Infiltration of genes from other breeds to Bengal Goat from Border States. However, it is expected that, in some pockets of West Bengal, mainly the islands of the Sunderban, pure variety of Bengal Goat is so far available. The Pure Bengal Goat breed also prevails in
Bangladesh.

In West Bengal small marginal and landless rural farmers traditionally rear goat. They generally follow the extensive management system, primarily with poor natural vegetation and crop stubbles, without any supplementation. By virtue of their higher fecundity and better productivity, goat assured income to the rural population with low input cost in diverse agroclimatic conditions.

In consideration to the above, a study was conducted to evaluate the social status of the Bengal Goat rearers and their native rearing practices in rural part of West Bengal. This will support in development of strategic improvement policies and necessary facilities for future betterment of the farmers.

\section{Material and Methods}

A total of 3000 families and 8750 Black Bengal goats were surveyed in different districts of West Bengal with following geographical locations.

1. District Nadia: $23^{\circ} 4^{\prime} \mathrm{N}$ and $88^{\circ} 5$ ' $\mathrm{E}$

2. District South 24 Paraganas : $22^{\circ} 53^{\prime} \mathrm{N}$ and $88^{\circ} 33^{\prime} \mathrm{E}$

3. District Paschim Medinipur : $22^{\circ} 25^{\prime} \mathrm{N}$ and $87^{\circ} 21^{\prime} \mathrm{E}$

4. District Malda : $25^{\circ} 00^{\prime} \mathrm{N}$ and $88^{\circ} 15^{\prime} \mathrm{E}$

5. District Hooghly: $22^{\circ} 52^{\prime} \mathrm{N}$ and $88^{\circ} 25^{\prime} \mathrm{E}$

The experiment is designed in to three modules: I. Socio economic status of Bengal Goat farmers; II. Rearing System of Bengal Goat \& III. Flock information of Bengal Goat.

In Module-I, data pertaining to Farmer's 
The rearing system of Black Bengal Goat and their farmers in West Bengal, India

\begin{tabular}{llr}
\hline Table-1. Socio Economics of Black Bengal Goat Farmers. \\
\hline SI. No. & Socio economic status of farmer & Number (\%) \\
\hline 1. & Caste & $1349(44.97)$ \\
& Schedule caste & $789(26.30)$ \\
& General & $729(24.30)$ \\
& Schedule Tribe & $133(4.42)$ \\
OBC & & $2739(91.3)$ \\
& Sex of Farmers & $261(8.7)$ \\
3. & Women & \\
& Men & $63(24.14)$ \\
& Education of Farmers & $173(66.28)$ \\
& Illiterate male & $25(9.58)$ \\
& Primary standard male & $1135(41.44)$ \\
& Secondary standard male & $1435(52.39)$ \\
4. & Illiterate female & $169(6.17)$ \\
& primary standard female & $1743(58.10)$ \\
& Secondary standard female & $846(28.20)$ \\
& Occupation of Farmers & $288(9.60)$ \\
& Landless small marginal farmer & $123(4.10)$ \\
5. & Agricultural labourer & $1934(64.47)$ \\
& Small business holders & $802(26.73)$ \\
& Service man & $264(8.80)$
\end{tabular}

different socio economics parameters Viz. Caste, Educational status, Main occupation, and Annual income are collected by participatory method. Module -II is designed to collect data on System of Goat rearing by gathering information on system of housing, grazing, drinking, tethering and sale pattern. The last Module (module-III) is designed to collect information of goat flock and data pertaining to flock size, Male to female ratio, morbidity \& mortality and annual production trends in terms of litter size, sale age and sale weight were collected and the data were computerized and analyzed to know about different factors of goat farming as well as farmers.

\section{Results}

The results of the survey under three modules are as follows.

I. Socio economic status of Bengal Goat farmers: Socio-economics of the goat farmers are presented in Table -1 .

A. Caste: Analysis of the data revealed that the goat farming is much popular amongst the Scheduled Caste (SC) $(44.97 \%)$, followed by General castes $(26.30 \%)$ and by Scheduled Tribe (ST) community (24.30\%), whereas only $4.42 \%$ of goat farmers belong to other backward community (OBC).

B. Sex: Women play major role $(91.3 \%)$ in the rearing of adult as well as young kids. However, the male members of the family used to sell or market the animals. Almost $100 \%$ role is being played by the women in washing and cleaning of goat houses and feeding of goats. However, child members play certain role $(20 \%)$ in grazing and kid rearing. Breeding of the does are mostly arrange by male member $(65 \%)$, while parturition was attended by the female members.

C. Educational Status: Maximum goat farmers are illiterate in both sexes. The educational status has been classified in Table -1. Male (66.28\%) farmers are more literate than the female (52.39\%) farmers.

D. Main Occupation: Goat farming is much popular amongst the landless, small \& marginal farmers $(58.1 \%)$ followed by the agricultural labourer $(28.2 \%)$, whereas, only $9.6 \%$ of small business holders and $4.1 \%$ of service man are related with goat husbandry.

E. Annual Income: As depicted in Table -1, annual income of most of the goat farmers $(64.47 \%)$ is within Rs. 10,000 and $26.73 \%$ farmers earned INR 10,00020,000 respectively; only $8.80 \%$ farmers earned more than Rs. 20 thousands per year.

II. System of Rearing: Details of goat rearing system at village level are presented in Table 2 .

A. Goat Housing: Survey data indicated that $82.63 \%$ farmers housed their goats in kachcha house, $13.77 \%$ in other type of house and $3.6 \%$ in brick walled house. Floor is found to be earthen kachcha, brick finished or cemented in $86.47 \%, 11.20 \%$ and $2.33 \%$ cases respectively. In $91.33 \%$ goat houses, paddy straws are used as the roofing material. In $7.2 \%$ houses earthen tiles and in $0.84 \%$ houses tin and other materials were 
The rearing system of Black Bengal Goat and their farmers in West Bengal, India

\begin{tabular}{llc}
\hline Table-2. Goat housing and feeding system & \\
\hline Housing and Fedding & Type & Number (\%) \\
\hline Housing Characteristics & Housing type & $2479(82.63)$ \\
& Kachcha & $108(3.6)$ \\
& Brick walled house & $413(13.77)$ \\
& Others & $2594(86.47)$ \\
& Floor & $336(11.20)$ \\
& Earthen type & $70(2.33)$ \\
& Brick finished & $2013(67.1)$ \\
Housing Location & Cemented floor & $987(32.9)$ \\
& Attached with residence & $2898(96.60)$ \\
& Separate & $102(3.40)$ \\
& Grazing & $1193(39.77)$ \\
& Grazing from morning to noon & $1807(60.23)$ \\
& Grazing separately in morning \& afternoon & $1774(59.13)$ \\
& Tethering & $697(23.23)$ \\
& Adoption of tethering grazing & $529(17.64)$ \\
\hline
\end{tabular}

used. Regarding location of housing, $67.1 \%$ farmers keep their goats within their own house, $32.9 \%$ farmers use separate house adjacent to that of the farmer house.

B. Drinking Water: Goats are among the most efficient domestic animals in the use of water just next to Camel. Pond water as the source of drinking water for goats is found to be very common $(59.13 \%)$ and in only $23.23 \%$ cases farmers used water from well and $17.64 \%$ from tube well.

C. Grazing: The Bengal Goats collect their feeding requirements by grazing and foraging on natural vegetation in pasture land and even in river banks of costal region. From the survey data it was found that $100 \%$ of the goats were reared through grazing. Of this $96.6 \%$ farmers allow grazing their goats from morning to noon. Very few farmers allow animals to graze separately in morning and afternoon with a sort rest at noon. During critical period, $2 \%$ of the farmers mainly use mineral mixture and concentrate feed along with tree leaves and tree tops.

D. Tethering: About $39.77 \%$ of small flock holders use to rear goats by tethering where facilities for grazing are limited. This simple device has made possible of keeping goats out-of-doors and at the same time on a limited area.

\section{I I. Flock I nformation}

A. Flock Size: Bengal goats are non-migratory in nature. They are reared in small flocks following partial or extensive grazing management system. Intensifi-cation of cash crop production minimized the availability of green production resulting in reduction of flock size under individual holding. Majority of the goat farmers maintained a flock size of 1 to 4 goats $(56 \%)$. Of course, quite a good number of farmers also maintained the flock varying from 5 to 8 goats (33\%). However, flock sizes of more than 8 goats are very limited (11\%) (Table-3).

Poor landless or marginal farmers use to rear goat on the basis of sharing of kids (50:50) with other farmers. Men often migrate for work while women and children take care of this small docile breed.

B. Male to female ratio: It is observed that (Table -4) up to age of 12 month, the ratio of male to female goats is almost $1: 1$. But the proportion of males sharply declined after 1 year of age and it was only 1:88. Most of the castrated male goats are sold at the age of 9 to 12 months.

C. Disease Prevalence and Mortality: Black Bengal Goats reared in free ranged condition are usually not suffered from major disease problem for their high disease resilience capability. The breed is vulnerable to rain water and water logging conditions. Incidences of various clinical manifestations like diarrhoea, fever, respiratory distress, ectoparasitic infestation, alopecia are common in the breed. Their occurrences are presented in Table -5 .

Mortality under field condition following extensive or semi intensive management system is around $9.63 \%$. This result is comparable with the findings of All India Coordinated Research Project on Goat Improvement, Black Bengal Field Unit where mortality ranges from 4.98 to $10.72 \%$ (Annual Report, 2009-10, AICRP on Goat Improvement). The resistance of animal against various diseases varies differently. This depends on their resistant patterns; 
The rearing system of Black Bengal Goat and their farmers in West Bengal, India

Table-3. Flock strength of Bengal Goat.

\begin{tabular}{lll}
\hline & Flock size & \\
\hline Up to 4 & 5 to 8 & More than 8 \\
$1680(56 \%)$ & $990(33 \%)$ & $330(11 \%)$ \\
\hline
\end{tabular}

Table-4. Sex ratio of Bengal Goat at different age.

\begin{tabular}{lll}
\hline & Age Group & \\
\hline $0-3$ Month & $3-12$ Month & $>12$ Month \\
$47.9: 52.9$ & $50.6: 49.4$ & $1.13: 88.7$ \\
\hline
\end{tabular}

Table-5. I ncidence of different diseases (\%) in different age groups.

\begin{tabular}{lccc}
\hline Diseases & & Age groups & $>$ 8 month \\
\cline { 2 - 4 } & Up to 1 month & > 1 month to 8 month & 32.4 \\
\hline 1. Diarrhoea & 33.6 & 34.0 & 28.7 \\
2. Fever & 40.8 & 30.4 & 4.6 \\
3. Pneumonia & 56.5 & 38.9 & 29.7 \\
4. Ectoparasite & 15.4 & 54.9 & 68.6 \\
5. Allopacia & 2.5 & 28.9 & 19.7 \\
6. Anorexia & 54.1 & 26.2 & 19.2 \\
7. Dog bite & 34.6 & 46.1 & 54.5 \\
8. Pox & 8.4 & 37.1 & 49.1 \\
9. Misc. & 24.1 & 26.8 & \\
\hline
\end{tabular}

this can be quantified in terms of recovery rate observed as $42.6 \%$ and $77.7 \%$ for up to 1 month age and 1 to 8 months age respectively. Above 8 month age recovery rate is found to be $65.5 \%$.

\section{Conclusion}

In West Bengal about $72 \%$ of the population lives in the rural area. Their livelihood is characterized by small holdings or landlessness, illiteracy, unemployment and malnutrition. Many of these people resort to goat production to assist in reaching selfsufficiency. Women and teenagers employ their labour in goat rearing as a subsidiary occupation. Therefore, goats are considered to play important role in generating employment, income, capital, storage and improving household nutrition.

To enhance the production potential of the breed it is essential to introduce superior technologies and to create the necessary facilities of improved practices in goat keeping. The adoption of a specific practice is not the result of a single decision to act but series of actions and meaningful decisions, which can only be taken after judging the present scenario and there lies the importance of the present study.

\section{References}

1. Annual Report (2007-08): Govt. of West Bengal, Directorate of Animal Resources and Animal Health, N.S. Building, Kolkata - 700001.

2. Annual Report (2009-10): All India Coordinated Research Project on Goat Improvement, Black Bengal Field Unit, Department of Livestock Production Management, West Bengal University of Animal \& Fishery Sciences. 37K.B. Sarani, Kolkata-700 037.

3. Food and Agriculture Organization of the United Nations, Statistics (2005).

4. Manjunath B. Joshi, et.al.(2004): Phylogeography and origin of Indian Domestic Goats. Mol. Biol. Evol. 21 (3): 454-62. 